\title{
Nutritional, Minerals and Phytochemicals composition of Garcinia cola [Bitter cola] and Aframomum melegueta [Alligator pepper]
}

\author{
${ }^{1}$ Alaje D.O., ${ }^{2}$ Owolabi K.T., ${ }^{1}$ Olakunle T.P., ${ }^{3}$ Oluoti O.J., ${ }^{1}$ Adetuberu I.A. \\ ${ }^{1}$ Applied Sciences Department, Osun State Polytechnic, Iree \\ ${ }^{2}$ Science Laboratory Technology Department, Osun State Polytechnic, Iree \\ ${ }^{3}$ Food Science Technology Department, Osun state Polytechnic, Iree
}

\begin{abstract}
Samples of Garcinia cola and Aframomum melegueta were analyzed for their nutritional composition, minerals constituents and phytochemical composition. The result revealed presence of bioactive constituents comprising: Aframomum melegueta which has the highest protein and ash content of $7.18 \%$ and $2.47 \%$ respectively. Garcinia cola, has the least content of all nutrients considered but highest in moisture. The plants are good sources of minerals such as Phosphorus, Potassium, Magnesium, Calcium, Zinc, Manganese, Iron, Sodium and Copper. Phytochemical analysis revealed are flavonoids $(1.88-6.10 \mathrm{mg} / 100 \mathrm{~g})$, saponins $(12.00-1.23 \mathrm{mg} / 100 \mathrm{~g})$, tannins $(0.31-0.41 \mathrm{mg} / 100 \mathrm{~g})$, Alkaloids $(0.40-0.30 / 100)$ and phenols $(0.1-$ $0.09 \mathrm{mg} / 100 \mathrm{~g}$ ). The presence of these phytochemicals supports the use of these plants as antimicrobial agent. These components are responsible for their antioxidant, anticancer, antiviral, anti-inflammatory and antiallergic activities and supports the popular use of Garcinia cola and Aframomum melegueta in herbal medicine in Nigeria.
\end{abstract}

Keywords: Garcinia cola, Aframomum melegueta, bioactive compounds, Anti-inflammatory, herbal medicine, phytochemical.

\section{Introduction}

Garcinia cola [Bitter kola] and Aframomum melegueta [alligator pepper] are traditional plants which are often eaten as snacks especially among the elderly in Nigeria. Bitter kola (Garcinia cola) is also known as Africa wonder nut. It comes from Garcinia cola trees, which belongs to the family harbaceae and grows in coastal rainforests in the south western and south eastern parts of Nigeria. Traditionally, these nuts were chewed as a masticalory substance, to stimulate the flow of saliva (1) but are now widely consumed as snack in West and Central Africa. The kernels of the nuts are widely traded and eaten as a stimulant $(1,2)$. Bitter kola is also belived to be an aphrodisiac. Unlike other kolanuts however, bitter kola is believed to clean abdominal problems, when a lot of nuts are eaten (3).Extracts from the roots, barks seeds and fruit of these plants are used in the preparation of syrups and infusions in traditional medicine as cough suppressant and in the treatment of liver Garrhosis and hepatitis (4). In folk medicine, bitter kola is dried, ground and mixed with honey to make a traditional cough mixture. Alligator pepper (Aframomum melegueta) is a West Africa spice belonging to the plant family Zingberaceae. It is commonly known as guinea grains and is a close relative of the grain of paradise, which is obtained from the closely related species. Aframomum melegueta [alligator pepper] is sold as the entire pod containing the seed. Aframomum melegueta [alligator pepper] is a very popular spice used mainly as food, in brewing, and in veterinary and traditional medicine (5). It is also believed to have purgative and hemostatic properties and also to be very effective against schistomiasis (6).It is generally assumed that the active constituents contributing to these bioactive effects are the phytochemicals. (7). phytochemical are present in a variety of plants utilized as important components of both human and animal diet. These include fruits seeds herbs and vegetables Diets containing an abundance of fruits and vegetables are bioactive against a variety of diseases, particularly cardiovascular diseases (8). Phytochemical which promotes many ecological and physiological roles are widely distributed as plant constituents. Woodly plants can synthesize and accumulate in their cells a great variety of phytochemicals including Alkaloids, Flavonoids, Tannins, Cardiac glycosides, Phenolic compounds, and Saponins (9). This study revealed the fundamental scientific basis for the use of the seeds of these plants by determining the nutritional, mineral, and phytochemical composition present in the seed of Garcinal kola and Aframomum melegueta.

\section{Sampling and Sample Preparation}

\section{Materials and Method}

The Garcinia cola [Bitter kola] and Aframomum melegueta [alligator pepper] used were freshly harvested and purchased from local farmers at the Ila market in Osun State, Nigeria. The Garcinia cola [bitter kola] were wrapped in dry banana leaves (traditional method) for 3 weeks while the Aframomum melegueta 
[alligator pepper] pods were also left to dry in the sun for a week. The dried seeds sample, were grounded using laboratory mortar and pestle kept in a polythene bag ready for analysis. seed of Garcinia cola and Aframomum melegueta were each weighed $(1 \mathrm{~kg})$. the plant samples were sun dried and ground into uniform powder using masterchef blender and stored in airtight bottles till required analysis.

\section{Nutritional Analysis}

Standard methods of the Association of Official Analytical Chemist (10) were used to determine the moisture, crude protein, crude fat, total ash and crude fibre contents of the samples Garcinia cola and Aframomum melegueta (bitter kola and alligator pepper). Moisture content was determined by heating $2.0 \mathrm{~g}$ of each sample to a constant weight in a crucible placed in an oven maintained at $105^{\circ} \mathrm{C}$. The dry matter was used in the determination of the other parameters. Crude protein (\% total nitrogen x 6.25) was also determined by the kjeldahl method, using $2.0 \mathrm{~g}$ samples, crude fat were obtained by exhaustively extracting $5.0 \mathrm{~g}$ of each sample in a soxhlet apparatus using petroleum boiling point range $40-60^{\circ} \mathrm{C}$ as the extract. Ash content was determined by the incineration of $10.0 \mathrm{~g}$ samples placed in a muffle furnace maintained at $550^{\circ} \mathrm{C}$ for $5 \mathrm{hrs}$. Crude fibre were obtained by digesting $2.0 \mathrm{~g}$ of samples with $\mathrm{H}_{2} \mathrm{SO}_{4}$ and $\mathrm{NaOH}$ and incinerating the residue in a muffle furnace maintained at $550^{\circ} \mathrm{C}$ for $5 \mathrm{hrs}$, total carbohydrate was obtained by different method, each analysis was carried out in two places.

\section{Mineral Content Determination}

The mineral contents of each sample were determined by atomic absorption spectrophytometry after dry ashing of the samples. Each ash sample was transferred quantitatively into a conical flask and dissolved in $10 \mathrm{ml}$ of $3 \%$ Ferric chloride and the mixture was heated on a hot plate. The solution was heated on a hot plate. The solution was then filtered into a $100 \mathrm{ml}$ volumetric flask and made up to the mark with distilled water. The mineral contents (Potassium, Calcium, Magnesium, Iron, Zinc, Manganese and Phosphorus) of the solution were determined using atomic absorption spectrometer.

\section{Phytochemical Analysis}

Phytochemical screening was carried out on the obtained plant extracts (11).

\section{Quantitative Analysis of the Constituents \\ Test for Tannins}

$0.5 \mathrm{~g}$ of the dried powdered samples Garcinia cola and Aframomum melegueta (bitter cola and alligator pepper) were boiled in $20 \mathrm{ml}$ of water in a separate test tube and then filtered. A few drop of $0.1 \%$ ferric chloride was added and observed for brownish green or blue black.

\section{Test for Phlobatannin}

An aqueous extract of the plant samples Garcinia cola and Aframomum melegueta me (bitter cola and alligator pepper) was boiled with $1 \%$ aqueous hydrochloric and deposition of a red precipitate was taken as evidence for the presence of phlobatannin.

\section{Test for Saponins}

$2 \mathrm{~g}$ of the powdered samples Garcinia cola and Aframomum meiegueta (bitter cola and alligator pepper) was boiled in $20 \mathrm{ml}$ of distilled water in a water bath and filtered. $10 \mathrm{ml}$ of the filtrate was mixed with $5 \mathrm{ml}$ of distilled water and shaken vigorously for a stable resistant froth. The frothing was mixed with 3 drops of olive oil, shacked vigorously and then observed for the formation of emulsion.

\section{Test for Flavonoids}

$5 \mathrm{ml}$ of $10 \%$ dilute ammonia solution was added to a portion of the aqeous filterate of the plant extract, followed by addition of concentrated $\mathrm{H}_{2} \mathrm{SO}_{4}$. A yellow coloration observed in the extract indicated the presence of flavonoid.

\section{Test for Cardiac Glycosides}

$5 \mathrm{ml}$ of the extract was treated with $2 \mathrm{ml}$ of glacial acetic acid containing 1 drop of ferric chloride solution $(0.1 \%)$. This was underlayed with $1 \mathrm{ml}$ of concentrated $\mathrm{H}_{2} \mathrm{SO}_{4}$. A brown ring of the interface indicates deoxysugar characteristics of cardenolides. A violet ring may appear below the brown ring, while in the acetic layer, a greenish ring may form just gradually throughout thin layer.

\section{Preparation of Fat Free Samples}

$2 \mathrm{~g}$ of each sample were defatted with $100 \mathrm{ml}$ of diethyl either using a soxhlet apparatus for 2 hours.

\section{Determination of Total Phenols by Spectrometer Method}

For the extraction of the phenolic component, the fat free samples of each plants was boiled with $25 \mathrm{ml}$ of ether for 15 minutes. $2.5 \mathrm{ml}$ of the extract was pipette into a $25 \mathrm{ml}$ flask, and the $5 \mathrm{ml}$ of distilled water was added $1 \mathrm{ml}$ of ammonium hydroxide solution and $2.5 \mathrm{ml}$ of concentrated alcohol were also added. The samples 
were left to react for 30 minutes for colour development. The absorbance of the solution was read using a spectrophotometer at $505 \mathrm{~mm}$ wave lengths (12).

\section{Alkaloid Determination using Harborne (1973) Method}

$2.5 \mathrm{~g}$ of the samples were weighed into a $250 \mathrm{ml}$ beaker and $100 \mathrm{ml}$ cef $20 \%$ acetic acid in ethanol was added and covered to stand for 4 hours. This was filtered and the extract was concentrated using a water bath to one quarter (1/4) of the original volume. Concentrated ammonium hydroxide was completed the whole solution, was allowed to settle and the precipitate was collected by filter. The residue is alkaloid, which was dried and weighed.

\section{Tannin Determination by Van-Burden and Robinson Method (1981)}

$250 \mathrm{~g}$ of the samples was weighed into $100 \mathrm{ml}$ plastic bottle $25 \mathrm{ml}$ of distilled water was added and shaken for $1 \mathrm{hr}$ in a mechanical shaker. This was filtered into a $50 \mathrm{ml}$ volumetric flask and made up to the mark. Then $5 \mathrm{ml}$ of the filtrate was pipette out into a tube and mixed with $3 \mathrm{ml}$ of Ferric chloride in $0.1 \mathrm{~m} \mathrm{HCl}$ and $0.08 \mathrm{ml}$ potassium ferrocyanide. The absorbance was measured in a spectrophotometer at $120 \mathrm{Nm}$ wavelengths, within 10 minutes. A blank sample was prepared and the color also developed and was at the same wavelength. A standard was prepared using tannin acid to get 100ppm and measured (13).

\section{Saponin Determination using Obadoni and Ochuko, 2001}

$20 \mathrm{~g}$ of each ground plant samples were dispersed into $200 \mathrm{ml}$ conical flask contain $20 \%$ aqueous ethanol. The suspension was heated over a hot water bath for $4 \mathrm{hrs}$ with continuous stirring at about $55^{\circ} \mathrm{c}$. The mixture was filtered and the residue was re-extracted with another $200 \mathrm{ml}$ of $20 \%$ ethanol. The combined extracts were reduced to $40 \mathrm{ml}$ over water bath at about $90^{\circ} \mathrm{c}$. the concentrated was transferred into a $250 \mathrm{ml}$ separated funnel and $20 \mathrm{ml}$ of diethyl ether was added and shaken vigorously. The aqueous layer was recovered while the ether layer was discarded. The purification process was repeated by measured $60 \mathrm{ml}$ of $\mathrm{n}$-butanol was added and combined $\mathrm{n}$ - butanol extracts were washed twice with $10 \mathrm{ml}$ of $5 \%$ aqueous sodium chloride $(\mathrm{NaCl})$. The remaining solution was heated in a water bath. After evaporation, the samples were dried in a oven to a constant weight, and saponin content was determined.

\section{Flavonoid Determination by the Method of Boham and Kocipcia by Ozam (1974)}

$100 \mathrm{~g}$ of each plant samples were extracted repeatedly with $100 \mathrm{ml}$ of $80 \%$ aqueous methanol at room temperature. The whole solution was filtered through Whitman filter paper No.42 $(125 \mathrm{~mm})$. The filtrate was later transferred into crucible and evaporated by dryness over water bath and weighed.

\section{Results and Discussion}

Table 1: Nutritional Composition (\%) of Garcinia cola and Aframomum melegueta

\begin{tabular}{|l|l|l|}
\hline Constituents & Garcinia Kola & Aframomum melegueta \\
\hline Moisture & $59.46 \pm 0.06$ & $13.66 \pm 0.18$ \\
\hline Dry Matter & $39.63 \pm 0.05$ & $84.50 \pm 0.17$ \\
\hline Crude Fat & $4.48 \pm 0.55$ & $2.60 \pm 0.31$ \\
\hline Crude Protein & $2.48 \pm 0.10$ & $7.20 \pm 0.05$ \\
\hline Ash & $0.88 \pm 0.006$ & $2.50 \pm 0.08$ \\
\hline Crude Fibre & $5.01 \pm 0.15$ & $5.54 \pm 0.13$ \\
\hline Total Carbohydrates & 27.69 & 31.50 \\
\hline
\end{tabular}

Table 2: Mineral Composition of Garcinia kola and Aframomum melegueta

\begin{tabular}{|l|l|l|}
\hline Mineral & Garcinia Kola & Aframomum melegueta \\
\hline Magnesium & $0.42 \pm 0.30$ & $0.33 \pm 0.11$ \\
\hline Calcium & $1.80 \pm 0.40$ & $0.26 \pm 0.20$ \\
\hline Potassium & $2.50 \pm 0.10$ & $0.65 \pm 0.01$ \\
\hline Phosphorous & $0.33 \pm 0.10$ & $1.60 \pm 0.22$ \\
\hline Sodium & $0.72 \pm 0.10$ & $0.45 \pm 0.02$ \\
\hline Iron & $17.75 \pm 0.30$ & $1.80 \pm 0.02$ \\
\hline
\end{tabular}


Nutritional, Minerals and Phytochemicals composition of Garcinia cola[Bitter cola] and

\begin{tabular}{|l|l|l|}
\hline Zinc & $2.30 \pm 0.01$ & $0.02 \pm 0.11$ \\
\hline Manganese & $0.78 \pm 0.20$ & $0.63 \pm 0.22$ \\
\hline Copper & $2.01 \pm 0.50$ & $0.17 \pm 0.10$ \\
\hline Chromium & 0.00 & 0.00 \\
\hline Cobalt & $0.55 \pm 0.20$ & 0.00 \\
\hline Cadmium & $0.29 \pm 0.10$ & 0.00 \\
\hline
\end{tabular}

Results are means values \pm standard deviation of two places determinations.

Table 3: Phytochemical Constituents of the Seeds of Garcinia cola and Aframomum melegueta

\begin{tabular}{|l|c|c|}
\hline Constituents & Garcinia cola & Aframomum melegueta \\
\hline Tannin & + & + \\
\hline Saponin & + & + \\
\hline Steroid & + & + \\
\hline Terpernoids & + & + \\
\hline Cardiac glucoside & + & + \\
\hline Alkanoid & + & + \\
\hline Phlobatannins & - & - \\
\hline
\end{tabular}

Key : + indicate present, - indicate Not present.

Table 4: Phytochemical Composition of Garcinia cola and Aframomum melegueta on dry weight basis expressed as $\mathrm{mg} / \mathbf{1 0 0}^{-1} \mathrm{~g}$.

\begin{tabular}{|l|c|c|}
\hline Constituents & Garcinia cola & Aframomum melegueta \\
\hline Phenols & $0.1 \pm 0.20$ & $0.09 \pm 0.10$ \\
\hline Alkanoids & $0.40 \pm 0.10$ & $0.30 \pm 0.20$ \\
\hline Tannins & $0.31 \pm 0.20$ & $0.41 \pm 0.11$ \\
\hline Saponins & $12.00 \pm 0.10$ & $1.23 \pm 0.30$ \\
\hline Flavonoids & $1.88 \pm 0.20$ & $6.10 \pm 0.10$ \\
\hline
\end{tabular}

Results are mean of live determination dry weight basis \pm standard deviation.

\section{Results}

The nutritional composition of Garcinia cola [bitter kola] and Aframomum melegueta [alligator pepper] are shown

Table 1. Garcinia cola contain highest amount of moisture while Aframomum melegueta has the least amount of moisture. Quantitative estimates of other nutritional fat, solid matter, ash, protein and crude fibre were also detected in both seeds.

The results of the mineral composition showed that Garcinia cola and Aframomum melegueta seeds constitute a rich source of mineral elements. Calcium was the most abundant element available in Garcinia cola seed $\left(1.80 \mathrm{mg} 100^{-1} \mathrm{~g}\right)$, followed by potassium $\left(2.50 \mathrm{mg} 100^{-1} \mathrm{~g}\right)$ while Aframomum melegueta contain $0.26 \mathrm{mg} 100^{-1} \mathrm{~g}$ of

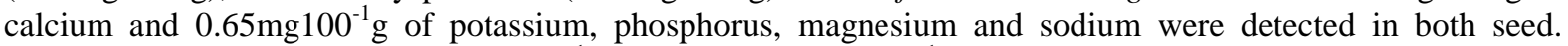
Enormous quantity of iron $\left(17.75 \mathrm{mg}_{100^{-1}} \mathrm{~g}\right)$ and zinc $\left(2.30 \mathrm{mg} 100^{-1} \mathrm{~g}\right)$ were detected in Garcinia cola seed while

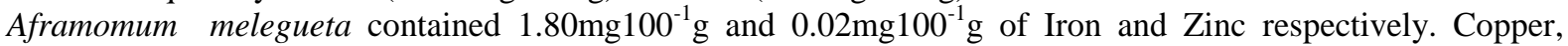
Manganese and Cobalt were available in Garcinia cola seed while Chromium was not detected in Garrcinia cola and Aframomum melegueta seeds (Table 2).

Table 3; indicates the phytochemical composition of Garcinia cola and Aframomum melegueta which reveald the presence of Tannin, Saponin, Flavonoid, Steroid, Terpernoids, Cardiac glycoside, Alkaloids and Phenol while absence of Phlobatannins in both seeds.

The phytochemical constituents of the seeds of Garcinia cola and Aframomum melegueta on dry weight basis are shown in table 4. The concentration of Saponin was higher in Garcinia cola $\left(12.00 \mathrm{mg} 100^{-1 \mathrm{~g}}\right)$ than in Aframomum melegueta which contain $\left(1.23 \mathrm{mg}^{100-1} \mathrm{~g}\right)$. Aframomum melegueta contained more Flavoniod $\left(6.10 \mathrm{mg}^{1000-1}\right)$ and Tannin $\left(0.31 \mathrm{mg}^{100-1} \mathrm{~g}\right)$ while Garcinia cola contained $1.88 \mathrm{mg}^{100-1} \mathrm{~g}$ of Flavoniods and $0.31 \mathrm{mg}^{100-1} \mathrm{~g}$ of tannins respectively.

Quantitative estimates of other phytochemicals shows that Garcinia cola contained $0.40 \mathrm{mg}^{100-1} \mathrm{~g}$ of Alkaloids Aframomum meleguata contained $0.30 \mathrm{mg}^{100-1} \mathrm{~g}$ of Alkaloids. Phenol were detected in Garcinia cola are higher $\left(0.10 \mathrm{mg}^{100-1} \mathrm{~g}\right)$ than Aframomum melegueta which contain least Phenol $\left(0.10 \mathrm{mg}^{100-1} \mathrm{~g}\right)$. 


\section{Discussion}

The result of nutritional composition (presented a table 1) shows that Aframomum melegueta has the least amount of moisture. Since, it is sample subjected to drying before consumption, unlike the other nuts that are prevented from losing moisture by wrapping them in fresh banana leaves. Consequently, Aframomum melegueta has the highest solid matter also appears to be the most nutritious of the traditional snacks having $7.20 \%$ protein and $2.50 \%$ ash which can be used in treating the obesity (14).

The nutrients composition of ash, protein and crude fibres contents were obtained in the Garcinia cola $(2.48 \%$, $0.88 \%$ and $5.01 \%$ respectively). These values are different from what had previously reported for Garcinia cola. (15) reported a protein content of $2.48 \%$, liquid $4.51 \%$, ash of $0.79 \%$ and crude fibres content of $5.23 \%$ in the seed.

The varying composition reported by various these snacks vary with season, environment and condition or time evaluation.

The results of the mineral composition clearly indicate that Garcinia cola and Aframomum melegueta seeds contain rich source of mineral elements. This becomes important when the usefulness of such mineral like Phosphorus, Calcium, Magnesium, Potassium, Iron and Zinc in the body considered. The Zinc content could mean that the plants can play a valuable role in the management of diabetes, which results from insulin malfunctioning. Zinc is essential for the production of insulin, a hormone and carbonic anhydrase, an enzyme in the body (9). Iron is a component of hemoglobin. It helps oxygen transport. Iron together with hemoglobin and ferrodizin plays important role in man's metabolism (9).

However, the lower sodium content of Garcinia cola and Aframomum melegueta might be an added advantage due to the direct relationship of sodium intake with hypertension in human (16).

Aframomum melegueta and Garcinia cola seeds are rich in phytonutrient such as Flavonoids, Phenolic compound, Tannins, Saponin, Terpernoids, cardiac glycosides and Alkaloids.

The biological function of flavonoids protection against platelet ulcers, viruses, and tumors (9). This may be the reason behind the use of extracts of this plant in the treatment of intestinal troubles in herbal medicine (9), the presence of phenolic compounds in the seed of Aframomum melegeuta and Garinia cola indicates that this plant might be an antimicrobial agent. This is because Phenols and Phenolic compounds have been extensively used in disinfection and remain the standard with which other bactericides are compared. Phenolic compounds as electron donors are readily oxidized to from Phenolate ion or quinine, an electron acceptor. This gives rise to practical uses. Protonated Phenol is used as cleaning agent. Extracts from Aframomium melegueta and Garcinia cola therefore have potent bactericidal properties (9). These findings supported the use of extract from Garcinia cola and Aframomum melegueta in preventing the formation of wound infections and also in treating wounds that not only heals fast (9).

The presence of Phenol further indicated that the seed of Garcinia cola and Aframomum melegueta could act as anti-inflammatory, anticlotting and immune enhancers. Phenols have been the subjects of extensive research as disease preventatives (17). Phenols have been responsible in having the ability to block specific enzymes that causes inflammation.

Garcinia cola and Aframomum melegueta seeds have high quality of Saponin content. Some of the general characteristics of Saponin include formation of foams in aqeous solution; cholesterol binding properties and bitterness (18).

Apart from Saponin, other secondary metabolite constituents of Garcinia cola and Aframomum melegueta detected include the Alkaloids and Tannins. Alkaloids ranked the most efficient therapeutically significant plant substance. Pure isolated plant Alkaloids and their synthetic derivatives are used as basic medicinal agents for their analgesic and bactericidal effects (19). They exhibit marked physiological activity when administered to animals. The high Tannin content could be partly responsible for the bitter principle associated with the raw seeds of Garcinia cola and hot, bitter and pungency of Aframomum melegueta seed. Tannins have a stringent properties, hasten the healing of wounds and inflamed mucous membrane (9). The presence of Tannins Aframomum melegueta and Garcinia cola strongly supports their use in treating wounds, hemorrhoids and burns in herbal medicine (20).

The present study has verified the usefulness of Garcinia cola and Aframomum melegueta seeds for nutritional and medicinal purpose. This party explained the use of these plant materials in herbal medicine. As rich source of phytochemicals couple with the presence of the essential vitamins and minerals. Garcinia cola and Aframomum melegueta seeds can be seen as a potential source of useful foods and drugs formulation. The uses of these plants for the treatment of the disease as claimed by traditional healer are also being investigated.

\section{Conclusion}

Conclusively, one can conclude that from the results of the nutrient and mineral composition Aframomum melegueta is the most nutritious of the two 'snacks' investigated except for a few minerals that are absent in it. 
Garcinia cola and Aframomum melegueta can be of immense use in phytomedicine and can be included in health care delivery system particularly in the developing economics. It can be concluded from this reports that the extracts from the seeds of Garcinia cola and Aframomum melegueta revealed the presence of phytochemical supports its uses as antimicrobial agent.

\section{Recommendation}

Garcinia cola [Bitter kola] can be recommended in folk medicine with honey mixed to make a traditional cough mixture, without any mixed it can also be used as an appetizer when there is indigestive. While the Aframomum melegueta [alligator pepper its can be used to cure Schistosomiasis japanicon, Schistosomiasis masomani.

\section{Reference}

[1]. Leakey R. (2001). Potential for novel food production from agroforestry trees: A review, http/www.wanatca. org. aulacotan c/papers/leakey-1

[2]. Omode A.A., Fatoki O.S., Olagun K.A. (1995). Physic-chemical properties of some underexploited and unconventional oilseeds J. Agric. Food chem.. 43:2850-2851

[3]. Onochie CFA,. Stan field D.F. (1960), Nigeria trees. Gov. Printer, Lagos, Nigeria Pp. 5-10

[4]. Iwu, M.M., 1986. Esearch finding on the possible Applications of Nigeria's Raw materials on thepharmaceutical industries in industrial potentials of Nigeria raw materials. Proceedings Ed J.K, Onoh, pp: 251-264.

[5]. Igwe et al, Emeruwa LC, Modie J.A (1999), ocular toxicity of Afrornomium melegueta (alligator pepper) on healthy Igbo of Nigeria J. Ethnopham acol 65 (3):203-206.

[6]. http//www.trpilascom/nengrekon dreprepre htm/ .alligatorpepperwikipedia.http// en. Wikipediaorg/wik/kolanut.

[7]. Okwu, D.E. (2003). Investigation into the medicinal and nutritional potential of gacinia kola (bitter kola) Heckel and Dennettia tripetala G. Bakker, Ph.D. Dissertation of Micheal Okpara University of Agricultu Umudike, Nigeria, pp: 5-10.

[8]. Uruquiaga, I. and F. Leighton, 2000. Plantpolyphenol antioxidants and oxidative stress Biological research, 33: 159-165.

[9]. Okwu, D.E, 2004. Phytochemicals and vitamin content of indigenous spices of South Eastern Nigeria. J. Sustain Agric. Environ., 6: 30-34.

[10]. AOAC (1990). Official methods of Analytical Chemist, Washington, DC.

[11]. Okwu D.E and O.D omodamiro, 2005. Effect of hexane extract and phytochemical content of Xcylopia acthiopica and Ocimum gratissimum on the uterous of Guinea pig.. Bio-Res., 3:(in press),

[12]. Obadoni B.O ., P.O. Ochuko. 2001. Phytochemical studies and cooperative efficacy of the crude extract of some homeostatic plant in Edo and Delta State of Nigeria. Global J. Pure and applied science, 8:203-208.

[13]. Van-Burden, T.P., Robinson, W.C. (1981). Formation of complexes between protein and Tannin acid. Journal of Agriculture and Food Chemistry.

[14]. Okwu, D.E. and M.E Okwu, 2004. Chemical composition of spondias mombia linn plant parts. $J$ sustains. Agric. Environ., 6: 140- 147.

[15]. Odebunmi, E.O, Oluwaniyi, O.O., Awolola G.V. and Adediji O.O. (2009) proximate and nutritional composition of kolanut (cola nitrida), bitter cola (garcinia kola) and alligator pepper (Aframomum melegueta). Polish African journal of Biotechnology 8(2). 308-310

[16]. Dahl, L.K .,1972. Salt and Hypertension. America J. Clin. Nutr., 25:231-238.

[17]. Duke, J., 1992. Handbook of biological active phytochemicals and their activities. BOCA Raton (FL) CRC Press, pp: 99-131.

[18]. Sodipo, O.A and J.A Akiniyi, 2000. Studies on certain characteristics of extract from back of Palmsinystalia macruceras (K.schum) Pierre Esbeille. Global J. pure and Applied Science, 6:83-87.

[19]. Stray, F.1998. The Natural Guide to medicinal Herbs and plant Tiger Books International, London, pp: $12-16$

[20]. Igboko, D.O, 1983 Phytochemical studies on Garcinia Kola Heckel. M.Sc. Thesis. University of Nigeria Nsukka Nigeria, PP:202. 